\title{
Effect of resource-based instructions on pre-service biology teachers' motivation toward learning biology
}

\author{
Josiane Mukagihana ${ }^{1}$, Florien Nsanganwimana ${ }^{2}$ and Catherine M. Aurah ${ }^{3}$ \\ ${ }^{1}$ African Centre of Excellence for Innovative Teaching and Learning Mathematics and Science \\ (ACEITLMS), University of Rwanda-College of Education (URCE), Rwamagana, Rwanda \\ ${ }^{2}$ University of Rwanda-College of Education (URCE), Rwamagana, Rwanda \\ ${ }^{3}$ Masinde Muliro University, of Science and Technology, Kakamega, Kenya
}

Linking motivation and learning is central to understanding students' motivation toward learning and learning itself as complex cognitive phenomena. Some studies focused on students' motivation toward learning biology in general; however, the shortage of studies on the effect of animation-based instruction and small-group laboratory activities as Resource-based Instructions (RBIs) on pre-service biology teachers was realized. The present study aimed to determine the effect of resourcebased Instructions on pre-service biology teachers' academic motivation toward learning biology at private and public Universities in Rwanda. Pre-service biology teachers were grouped into three groups at a public teacher traning University and received a pre-and post-assessment. Quasi-experimental, pre and post-test control group design was used at a public university, while a repeated measures design was used at a private university. The standard academic motivation scale for learning biology (AMSLB) yielded a Cronbach alpha coefficient of 0.71 before use. The t-Test was computed to measure the statistically significant difference between the preand post-assessment scores and group of RBI interventions. Multivariate analysis (MANOVA) was computed to measure the effect of RBIs vis à vis the AMSLB factors. Findings revealed no statistically significant difference $(\mathrm{df}=18, p=.458)$ in the motivation of learning biology of pre-service teachers before and after learning via traditional instruction at a public university. However, a statistically signficant difference was found with animation instruction ( $\mathrm{df}=18, p=.002$ ) and lab instruction $(\mathrm{df}=18, p=.014)$. The motivation of learning biology increased at a public university than at a private university. However, animations and small-group lab activities increased pre-service biology teachers' intrinsic and extrinsic-career motivation of learning biology at both universities. Therefore, the study recommends using RBIs to improve pre-service biology teachers' motivation toward learning biology.

\section{ARTICLE DETAILS}

LUMAT General Issue Vol 9 No 1 (2021), 873-891

Received 27 July 2021 Accepted 22 November 2021 Published 3 December 2021

Pages: 19

References: 39

Correspondence: joaxmuka@yahoo.fr

https://doi.org/10.31129/ LUMAT.9.1.1637

Keywords: Academic motivation, resource-based instructions, learning biology, pre-service biology teachers, university, Rwanda

\section{Introduction}

Biology is a science subject that informs the world about all aspects of life. Its teaching and learning increase knowledge of life sciences (Özbaş, 2019). Some studies reported that students showed a good interest in learning biology (Koul et al., 2011; Prokop et al., 2007); however, some difficulties in learning biology like teachers teaching strategies and lack of learning stimulus resources, among others, were pointed out 
(Çimer, 2012). Teaching and learning biology require a motivating teaching and learning environment where student's involvement is taken into account. This is imperative based on the biological concepts that many are experimental in nature and challenge interested students to learn and work on the concepts (Cuthbert, 2005; Dohn et al., 2016; Şen et al., 2014).

Linking motivation and learning is central to understanding students' stimulus toward learning and learning themselves as complex cognitive phenomena (Jurisevic et al., 2008). Cuthbert (2005) defined learning as ontogenetic adaptations that mean the changes in an organism's behavior due to the regularities from its environments. Jurisevic et al. (2008) added that motivation to learn is a behavioral factor defined by different elements of motivation like interests, goals, attributes, self-image, and external enticements. The literature emphasized that motivation to learn is a crucial factor in learning science and interactions between different learning domains like cognitive and affective with intrinsic or extrinsic motivation (Shin et al., 2017).

In the present study, academic motivation was discussed in three different factors pointed by self-determination theory (Ryan \& Deci, 2000) as intrinsic motivation, extrinsic motivation, and amotivation. Different studies Ayub (2010); Covington \& Müeller, (2001); Jurisevic et al., (2008); Reiss (2012) and Ryan \& Deci (2000) discussed intrinsic and extrinsic motivation to learn. All authors defined the terms and came up with a similar description stating intrinsic motivation as an act of doing something because it is inherently interesting, enjoyable, or satisfying to someone. Simply intrinsic motivation is characterized by doing things without any reason or expected benefits. At the same time, extrinsic motivation was seen as pursuing something without its own sake. In other words, to engage in an activity with an end of achieving the goal. For instance, students extrinsically may be motivated to perform better in a competition or test to achieve a good grade, please their parents, get a reward, or skip a punishment (Gilakjani et al., 2012).

According to Ryan and Deci (2000), amotivation is the third factor or type of motivation that announces the absence of an individual intention to act. Amotivated students do not accord any disparity to a learning activity, feel incompetent toward activity, lose interest, and find no enjoyment or reason to do an activity. In their queries, there is "why to join the school," a behavioral question that may result in low academic achievement or school dropout as advocated that students with low performance showed low motivational belief (Ekici, 2010). 
Apart from amotivation, motivation has a crucial role in education. Şen et al. (2014) stated that motivational belief in students exerts a direct impact on their academic achievement. Ayub (2010) added that intrinsic motivation significantly impacts students' academic learning and competency, while career motivation, a form of extrinsic motivation, plays an essential role in supporting students in choosing science subjects for learning, especially STEM Choice (Shin et al., 2017). Chua and Karpudewan (2017) added that the extent of motivation in students toward active learning environments like laboratories predicts their attitude toward science learning. Hence, investigating the effect of factors influencing motivation in students like university students is an imperative need.

Different factors have been shown to influence students' motivation to learn biology, and among others, instructional methods influence learning motivation differently. Keraro et al. (2007) advocated that students showed a high motivation toward learning biology after being treated by cooperative concept mapping teaching approach, while in the study by Özarslan and Çetin (2018), biology projects proved negative effect on students" motivation toward learning biology. Online teaching did not display a significant difference in improving student motivation toward learning biology in comparison to traditional instructional methods (Bulic \& Blazevic, 2020). Hence, it is imperative to test the motivational level in pre-service biology teachers' after being treated by animation-based instructions and small-group laboratory activities. For instance, a study by Mukagihana et al. (2021) found that students were motivated during learning microbiology through small groups and were excited to manipulate computer animations. Such instructions also demonstrated a rise in students' positive attitudes toward learning biology (Mukagihana et al., 2021). In the latter study, the students were motivated during learning through the teaching and learning bucket model. This is a lecturer backing and learners owning learning model (Ndihokubwayo et al., 2021) interested students in collaboratively constructing improvised materials (Ndihokubwayo et al., 2019) and presenting their outcome to the whole class. Kibga et al.'s (2021) study showed a significant increase in students' curiosity among secondary schools in Tanzania due to the implementation of handson activities as an instructional strategy. In other studies, innovative collaborative instructional strategies moderated students' verbal ability and their achievement in biology (Adejimi et al., 2021) and motivation toward learning biology (Dohn et al., 2016; Hewitt et al., 2019). 
In general, studies by Dohn et al. (2016), Mnguni (2018), Özbaş (2019), and Kişoğlu (2018) were interested in finding out the students motivation toward learning biology; however, the literature lacks sufficient studies on pre-service biology teachers motivation toward learning biology. Besides, the effect of different instructional methods on student's motivation toward learning biology was found out (Bulic \& Blazevic, 2020; Corkin et al., 2017; Dyrberg et al., 2017; Hewitt et al., 2019; Keraro et al., 2007; Özarslan \& Çetin, 2018), but minor studies focused on the effect of resourcebased instructions on pre-service biology teacher's motivation toward learning biology. Likewise, a recent study done in higher learning institutions in Rwanda (Mukagihana et al., 2020) showed low use of resource-based instructional tools prevailed to teach and learn biology. Therefore, to bridge the gap, this study aimed to determine the effect of animation-based instruction and small group laboratory activities as resource-based instructions on pre-service biology teachers' motivation to learn biology.

Self- determination theory (SDT), as described by Cook \& Artino (2016) and Deci \& Ryan (1985), guides the study. The theory postulates that innately human is motivated and need to be self-directed in activities they find inherently enjoyable. This reflects on intrinsic motivation, which primarily is not influenced but innate. Sometimes, humans may be influenced to do an inherently enjoyable activity to earn an instrumental value that generates extrinsic motivation in various forms such as career, goals, societal values, rewards, and others. The theory relates to this study which sought to determine the effect of resource-based instructions on pre-service biology teachers' motivation toward learning biology. In the study, motivation is conceptualized in its three different factors as intrinsic motivation, amotivation, and extrinsic motivation in two forms, career goals, and social values.

Motivation toward learning proved its essential role in learning science concepts (Shin et al., 2017). The present study significantly contributes by adding in literature the motivational level of pre-service biology teachers to learn biology at private and public teacher training Universities. Besides, it informs about the effect of animationbased instruction and small group laboratory activities on pre-service biology motivation to learn biology. Therefore, we aimed to measure the effect of animationbased instruction and small-group laboratory activities as resource-based instructions on pre-service biology teacher's motivation toward learning biology.

The study answered two research questions: 
1. What is the motivation of pre-service biology teachers toward learning biology at private and public teacher training Universities in Rwanda?

2. What effect do animation-based instruction and small group laboratory activities as resource-based instructions have on pre-service biology teacher's motivation toward learning biology?

We do hypothesize that:

Ho1: There is no statistically significant difference between pre-service biology teachers' motivational level taught by traditional methods and those taught by animation-based instruction or small group laboratory activities as resource-based instructions.

Ho2: There is no statistically significant difference in motivation toward learning biology between pre-service biology teachers at private and public universities.

\section{Methodology}

\subsection{Participants and sample}

The participant in the study consisted of fifty (50) pre-service biology teachers in year two at the University of Technology and Arts of Byumba (UTAB), a private university with biology education programs and one hundred and eighty (180) year two preservice biology teachers assigned to the study from a population of 528 at University of Rwanda College of Education (URCE), a public teacher training University. Thus a purposive sampling was used. The research unit and innovation at URCE granted ethical clearance, and the universities granted data collection approval before the conduct of the study, which was held from November 2020 to March 2021.

\subsection{Research design}

A survey design was embedded in a quasi-experimental non-equivalent control group design and repeated measures design to check the effect of resource-based instructions on pre-service biology teachers' motivation to learn biology. Repeated measures design is a longitudinal research design involving multiple measures of the same variable in which change over time is assessed (Creswell, 2014). Survey design is one of the procedures in quantitative research that support researchers to measure individuals' different aspects like emotions, attitudes, and opinions (Creswell, 2015). The survey was used to collect the data before and after treatment and permitted the 
researcher to measure the motivational level of pre-service biology teachers to learn biology as the effect of treatment.

\subsection{Research instruments}

The instrument used to collect the data is an adapted Academic Motivation Scale for Learning Biology (AMSLB) developed by Aydin et al. (2014). The scale comprises 19 statements distributed into four motivation factors or subscales named "Intrinsic motivation with six statements, amotivation with five statements, Extrinsic motivation - Career with four statements, and Extrinsic motivation - Social with four statements. Statements are scored from 1 to 5 with $1=$ Strongly disagree (SD), $2=$ Disagree (D), $3=$ No opinion, $4=$ Agree (A), and $5=$ Strongly agree (SA). All statements are positive except five statements in the amotivation factor. However, these items were similarly scored as others (SD, D, NO, A, and SA). We did not reverse the scales to avoid participants' confusion. Before using the scale, the items were rearranged in subscales or factors in an orderly manner. Thus "Intrinsic Motivation has statements 1 to 6, amotivation statements 7 to 11, and Extrinsic Motivation - Career statements 12 to 15, and extrinsic motivation -Social statements 16-19 (see Appendix A).

Statements in extrinsic motivations career factors were rephrased to relate them to pre-service biology teachers as university students. Furthermore, the instrument was subjected to one expert judge at Masinde Muliro University of Science and Technology and one at URCE for validity checking.

The AMSLB adapted to the Rwandan context was found to have significant reliability. Before using it, we tested it with 35 pre-service biology teachers at a university that did not participate in the study. We computed a correlation statistic using SPSS 23 and found a coefficient of 0.71 of Cronbach alpha. This informs that AMSLB is reliable, and its statements are internally consistent.

\subsection{Data collection procedures}

At the University of Technology and Arts of Byumba (UTAB), the participants consisted of a single group of fifty (50) pre-service biology teachers. The participants received a pre-assessment by answering the Academic Motivation Scale for Learning Biology (AMSLB) before receiving any treatments and a post-assessment after each treatment. They were treated by starting with traditional methods of teaching (Lecturer method), followed by treatment by animation-based instruction, and lastly by small group laboratory activities. It means that a post-assessment by AMSLB 
alternated with treatment in repeated measures as described in Creswell (2015). All 50 participants did not participate in the study; some attended pre-assessment but did not answer all post-assessment. Due to this, by data filtering, only 33 participants answered pre-assessment and all post-assessment by AMSLB.

Contrary, at the University of Rwanda College of Education (URCE), 179 preservice biology teachers were available on the starting day of data collection. They were randomly assigned to three groups as the control group $(\mathrm{N}=60)$ and two experimental groups. The first $(\mathrm{N}=59)$ was treated by animations-based instruction, and the second $(\mathrm{N}=60)$ was treated by laboratory method using small-group laboratory activities. One instructor carried out the instruction. This helped us minimize the instructor's threat of validity. Pre-service biology teachers in each group received a pre-assessment by administering AMSLB before receiving treatment and answered the same AMSLB as post-assessment after interventions. The intervention lasted for a semester, starting from November 2020 to March 2021 at both Universities. Concept of introduction to microbiology (history of microbiology, its scientists and their discoveries, types of microorganism), method and techniques for microorganism (gram staining), method of pure culture isolation (streak, spread, and pour method) were discussed.

In the control group, the course took place in the classroom. The instructor used a projector and drawing on a whiteboard, especially diagrams such as structures of bacteria, cell walls, etc. The animation group used animated lessons from YouTube. Introduction to microbiology was projected, and where necessary instructor intervened for more explanation. For other concepts, every concept had its animation. The animated video contained graphical images of lab practical and moving text. Thus, participants heard, watched what was being done, and then read related text. When having a question, the instructor stopped, and where challenges occur, she intervened. Small group lab group mainly studied in the lab. Group of 2 to 3 students (pre-service biology teachers) spent an amount of time in the lab. We first introduced lab rules, introduction to microbiology using a projector and showing the materials, provided lab procedure for each technique showing materials, reagents, and procedure. The instructor played the role of guidance while pre-service biology teachers (students) were conducting experiments. 


\subsection{Data Analysis}

Upon coming from the research field, we entered data in MS Excel 2016. The first column was filled with pre-service biology teachers' codes, while the first row was filled with Academic Motivation Scale for Learning Biology (AMSLB) statements (STAT). We entered the number scored by each participant-from 1 as strongly disagree to 5 as strongly agree-under each statement/item. One file contained data from URCE, while another file contained data from UTAB pre-service biology teachers. We first computed the average scores for each statement across all the participants before exporting the data into SPSS version 23. We analyzed the data using this software. We first computed mean scores from each intervention at URCEwhere three groups [Control group that was taught using lecture method, first experimental group that was taught using animation-based instruction, and second experimental group that was taught using small group laboratory activities] were tested twice via pre-and post-test design. At UTAB, a single group of the participant was tested four times via repeated measures [(a) before assessment, (b) after being taught by lecture method, (c) after being taught using animation-based instruction, and (d) after being taught using small group laboratory activities]. After computing the mean score of each group, the t-Test was computed to measure the statistically significant difference between the pre-and post-test (motivation assessment) and a group of RBI interventions. Lastly, multivariate analysis (MANOVA) was computed to measure the effect of resource-based instructions (RBIs) vis à vis the AMSLB factors.

\section{Findings and Discussion}

Table 1 shows the mean scores of pre-service biology teachers' answers on the Academic Motivation Scale for Learning Biology (AMSLB) before and after each intervention at both University of Rwanda College of Education (URCE) and the University of Technology and Arts of Byumba (UTAB). The means scores are computed on the Likert AMSLB scale. Thus, the lowest score is 1, while the highest score is 5 . At both universities, pre-service biology teachers showed a good intrinsic motivation before interventions in each group, with an average of pre-assessment above 4.o, in general interventions did not change their intrinsic motivation toward learning biology except in the control group after treatment with the traditional method, mean scores $\mathrm{AV}=4.50$ before treatment and mean scores $\mathrm{AV}=4.56$ after 
treatment at URCE. The mean score decrease for intrinsic motivation factor was realized at UTAB after intervention by small group lab activities (see Table 1). This is attributed to the effect of repeated testing. Although pre-service biology teachers generally hold a high intrinsic motivation, UR-CE pre-service biology teachers are intrinsically motivated than UTAB pre-service biology teachers (See Figure 1).

Even though pre-service biology teachers hold intrinsic motivation, they also expressed an amount of amotivation toward learning biology. Both traditional methods of teaching, animation-based instruction, and laboratory methods through small group lab activities decreased amotivation toward learning biology in all groups of pre-service biology teachers at URCE. This was not the case at UTAB due to repeated testing, where pre-service biology teachers taught in series of interventions continuously showed amotivation after treatment by traditional method and by small group lab activities see (Table 1). Amotivation was high in pre-service biology teachers at UTAB than URCE pre-service biology teachers (see Figure 1).

Traditional animation-based instructions and small group laboratory activities improved extrinsic motivation-career in pre-service biology teachers at UTAB after each intervention than it did at URCE; however, pre-service biology teachers at URCE hold high extrinsic motivation motivation-career than those at UTAB. Table 2 shows the average mean scores of extrinsic motivation-career before and after each intervention at both Universities. Generally, extrinsic motivation-social did not increase after interventions in all groups at both universities; however, this motivation was very high in pre-service biology teachers at UTAB than URCE before and after interventions. 
Table 1. Mean scores from AMSLB across Universities and Resource-based Instructions (RBIs)

\begin{tabular}{|c|c|c|c|c|c|c|c|c|c|c|c|}
\hline & & \multicolumn{6}{|l|}{ URCE } & \multicolumn{4}{|l|}{ UTAB } \\
\hline & & $\begin{array}{l}\text { Control } \\
\text { Pre }\end{array}$ & $\begin{array}{l}\text { Control } \\
\text { Post }\end{array}$ & $\begin{array}{l}\text { Animation } \\
\text { Pre }\end{array}$ & $\begin{array}{l}\text { Animation } \\
\text { Post }\end{array}$ & $\begin{array}{l}\text { Lab } \\
\text { Pre }\end{array}$ & $\begin{array}{l}\text { Lab } \\
\text { Post }\end{array}$ & $\begin{array}{l}\text { Pre- } \\
\text { assessment }\end{array}$ & Traditional & Animation & $\begin{array}{l}\text { Small } \\
\text { group Lab }\end{array}$ \\
\hline \multirow{7}{*}{ 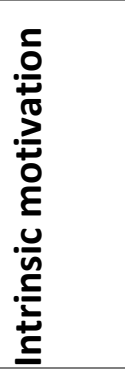 } & STAT1 & 4.60 & 4.65 & 4.36 & 4.25 & 4.32 & 4.28 & 4.42 & 4.48 & 4.33 & 4.09 \\
\hline & STAT2 & 4.55 & 4.58 & 4.46 & 4.29 & 4.37 & 4.37 & 4.42 & 4.36 & 4.21 & 4.12 \\
\hline & STAT3 & 4.65 & 4.65 & 4.29 & 4.15 & 4.60 & 4.31 & 4.42 & 4.52 & 4.39 & 4.15 \\
\hline & STAT4 & 4.62 & 4.65 & 4.47 & 4.34 & 4.45 & 4.28 & 4.30 & 4.39 & 4.48 & 4.21 \\
\hline & STAT5 & 4.63 & 4.68 & 4.47 & 4.29 & 4.43 & 4.32 & 4.18 & 4.27 & 4.18 & 4.03 \\
\hline & STAT6 & 3.95 & 4.13 & 4.03 & 4.02 & 3.83 & 3.88 & 2.88 & 2.09 & 2.42 & 2.85 \\
\hline & Average & 4.50 & 4.56 & 4.35 & 4.22 & 4.33 & 4.24 & 4.11 & 4.02 & 4.01 & 3.91 \\
\hline \multirow{6}{*}{ 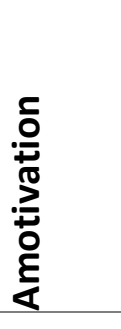 } & STAT7 & 1.28 & 1.30 & 1.86 & 1.78 & 1.83 & 1.80 & 2.21 & 2.33 & 2.18 & 2.30 \\
\hline & STAT8 & 1.60 & 1.52 & 1.83 & 1.80 & 1.83 & 1.85 & 2.30 & 2.22 & 2.12 & 2.24 \\
\hline & STAT9 & 1.33 & 1.32 & 1.64 & 1.71 & 1.77 & 1.55 & 2.03 & 2.09 & 2.09 & 2.12 \\
\hline & STAT10 & 1.67 & 1.62 & 1.81 & 1.81 & 1.85 & 1.75 & 2.12 & 2.24 & 2.30 & 2.33 \\
\hline & STAT11 & 1.58 & 1.52 & 1.93 & 1.80 & 1.68 & 1.63 & 3.30 & 3.85 & 3.39 & 3.15 \\
\hline & Average & 1.49 & 1.45 & 1.82 & 1.78 & 1.79 & 1.72 & 2.39 & 2.55 & 2.42 & 2.43 \\
\hline \multirow{5}{*}{ है } & STAT12 & 4.23 & 4.27 & 4.19 & 3.98 & 3.93 & 3.95 & 3.94 & 4.18 & 3.94 & 3.91 \\
\hline & STAT13 & 4.55 & 4.43 & 4.17 & 3.98 & 4.27 & 4.15 & 3.70 & 3.55 & 3.67 & 3.88 \\
\hline & STAT14 & 4.12 & 4.07 & 3.85 & 3.80 & 3.60 & 3.67 & 3.79 & 3.82 & 3.70 & 3.82 \\
\hline & STAT15 & 4.22 & 4.18 & 3.90 & 3.88 & 3.82 & 3.90 & 3.27 & 3.39 & 3.58 & 3.97 \\
\hline & Average & 4.28 & 4.24 & 4.03 & 3.91 & 3.90 & 3.92 & 3.67 & 3.73 & 3.72 & 3.89 \\
\hline \multirow{5}{*}{. } & STAT16 & 3.20 & 3.22 & 3.34 & 3.07 & 3.12 & 2.97 & 3.88 & 3.61 & 3.48 & 3.58 \\
\hline & STAT17 & 3.77 & 3.90 & 3.59 & 3.46 & 3.83 & 3.67 & 3.85 & 3.36 & 3.73 & 3.67 \\
\hline & STAT18 & 2.75 & 2.50 & 2.44 & 2.53 & 2.72 & 2.52 & 3.64 & 3.25 & 3.48 & 3.58 \\
\hline & STAT19 & 2.85 & 2.62 & 2.42 & 2.51 & 2.43 & 2.52 & 3.61 & 3.69 & 3.72 & 3.61 \\
\hline & Average & 3.14 & 3.06 & 2.95 & 2.89 & 3.03 & 2.92 & 3.74 & 3.48 & 3.60 & 3.61 \\
\hline
\end{tabular}


The t-Test of paired samples showed no statistically significant difference ( $\mathrm{df}=18$, $p=.458$ ) before and after learning via traditional instruction at URCE. However, it was shown by animation instruction $(\mathrm{df}=18, p=.002)$ and lab instruction $(\mathrm{df}=18, p=.014)$. Therefore, we reject the null hypothesis that there would not be a statistically significant difference in the motivational level of pre-service biology teachers taught by the traditional method and those taught by animation-based instruction or small group laboratory activities. Although the motivation of learning biology increased at URCE, this was not the case at UTAB. The t-Test of paired samples showed no statistically significant difference $(\mathrm{df}=18, p=.660)$ between pre-assessment and traditional instruction $(\mathrm{df}=18, p=.750)$ between traditional and animation instruction, and $(\mathrm{df}=18, p=.832)$ between animation and lab instruction.

The fact that animation-based instruction and small-group laboratory activities did not increase intrinsic motivation in pre-service biology teachers at UR-CE as did the traditional teaching method explains that pre-serve biology teachers in the two experimental groups learn biology for their own sake. Their motivation to learn biology is innate in them rather than stimulated by environmental factors. Inherently, they find biology enjoyable and interesting and learn with no purpose of avoiding like a failure or earning instrumental value. Being treated with resource-based instructions or not, they are always intrinsically motivated to learn biology. Their colleagues who were taught by traditional methods tend to increase their intrinsic motivation toward learning biology; this may mean that for their learning they like the traditional method of teaching or that they are used to learn with it or that traditional methods (lecture) are the easiest engaging instructional method for them to learn biology. This type of instructional method does not bring new or attractive instructional resources in a classroom environment that may challenge or stimulate students to learn with a mind to earn extrinsic incentives; thus, it increases pre-service biology teachers' innate enjoyment from learning biology. These findings are not consistent with the findings of Bye et al. (2007), who reported a high intrinsic motivation in students taught by non-traditional instructional methods.

Teaching pre-service biology teachers by series of interventions did not show a statistically significant difference in instructional methods. This does not mean that used instructional methods have no effect on motivation but rather may improve motivation toward learning biology at the same level. This similar statistically significant effect of animation-based instruction, small group laboratory activities, and traditional methods on motivation toward learning biology tells that at UTAB, 
pre-service biology teachers gained little motivation after learning by traditional, but did not increase by followed interventions. This lack of improvement may be caused by the repetition of learned content that characterizes interventions and creates a boring learning environment.

We hypothesized no statistically significant difference in motivation toward learning biology between pre-service biology teachers at a private university (UTAB) and a public university (URCE). Hence the hypothesis is consistent with the statistical results that proved that the difference between pre-service biology teachers' motivation toward learning biology at URCE and UTAB was not statistically significant ( $\mathrm{df}=1, p=123$ ) prior to $\mathrm{RBI}$ intervention. The finding informs that preservice biology teachers at private (UTAB) and at public university (URCE) are committed to learning biology and that both may be equally interested and skilled in learning biology. This implies that both pre-service biology teachers may be similarly competent in teaching biology at secondary schools after their studies.

Through the general linear model, MANOVA results are displayed in Figure 1. Four factors of AMSLB are displayed in the same figure at both universities. Although the difference between pre-service teachers at URCE and UTAB was not statistically significant $(\mathrm{df}=1, p=123)$, the four factors made this significant ( $\mathrm{df}=3, p=.003$ ). Preservice teachers at URCE and UTAB possess high intrinsic and extrinsic-career motivation of learning biology; however, URCE possesses such motivation higher than those at UTAB.

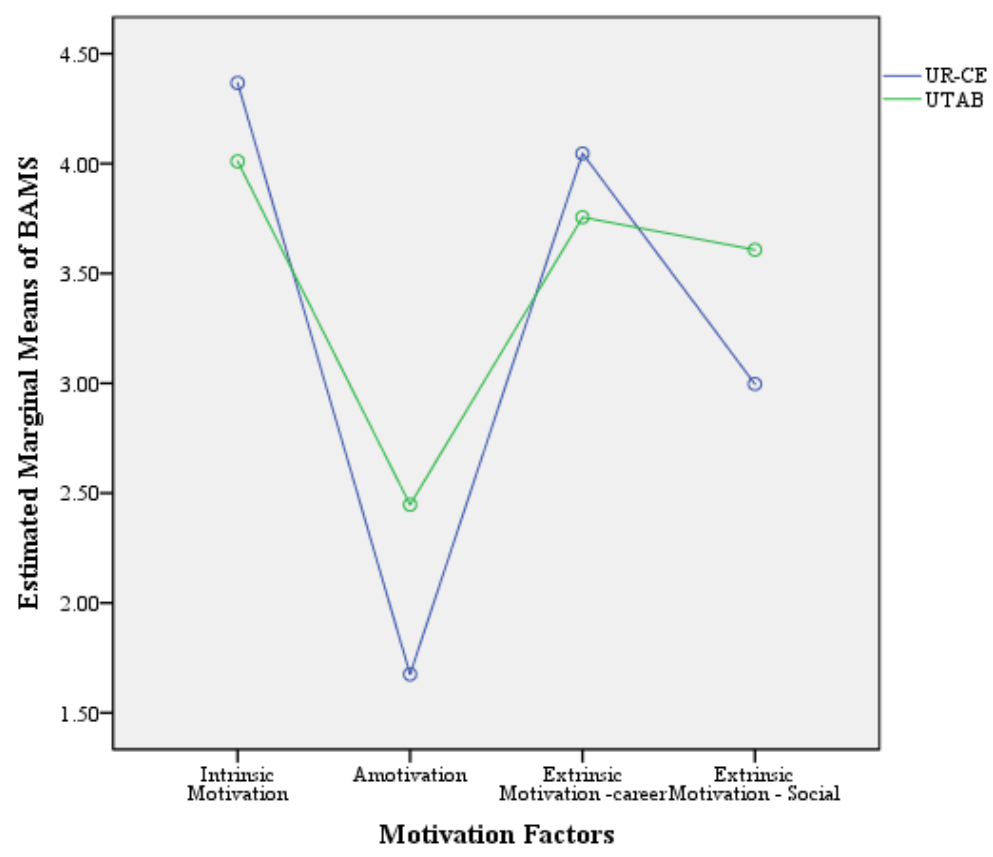

Figure 1. Academic Motivation Scale for Learning Biology (AMSLB) at different Universities 
Contrariwise, both pre-service biology teachers at URCE and UTAB possess low amotivation and extrinsic-social motivation of learning biology. UTAB possesses such motivation higher than those at URCE. The overall Levene's Test of Equality of Error Variances confirmed that the AMSLB factors displayed a high statistical significance between AMSLB factors $(\mathrm{F}=6.475, \mathrm{df} 1=3, \mathrm{df} 2=15, p=.005)$ at URCE. At the same time, this difference was not statistically significant $(\mathrm{F}=1.794, \mathrm{df} 1=3, \mathrm{df} 2=15$, $p=.191)$ at UTAB.

For further analysis, we analyzed each of four factors in AMSLB across RBIs intervention among pre-service-teachers both at URCE and UTAB (Table 2)

Table 2. Effect of RBIs on pre-service biology teachers' motivation toward learning biology, specifically across AMSLB Factors

\begin{tabular}{llllll}
\hline & RBIs Intervention & $\begin{array}{l}\text { Intrinsic } \\
\text { motivation }\end{array}$ & Amotivation & $\begin{array}{l}\text { Extrinsic } \\
\text { motivation } \\
\text { career }\end{array}$ & $\begin{array}{l}\text { Extrinsic } \\
\text { motivation } \\
\text { - social }\end{array}$ \\
\hline \multirow{2}{*}{ URCE } & Traditional [Pre vs Post] & 0.038 & 0.045 & 0.135 & 0.221 \\
& Animation [Pre vs Post] & 0.002 & 0.173 & 0.047 & 0.279 \\
& Lab [Pre vs Post] & 0.066 & 0.063 & 0.400 & 0.096 \\
\hline UTAB & Pre-assessment vs & 0.428 & 0.357 & 0.398 & 0.039 \\
& Traditional & & & & \\
& Traditional vs Animation & 0.488 & 0.381 & 0.469 & 0.172 \\
& Animation vs Lab & 0.404 & 0.485 & 0.041 & 0.489 \\
\hline *Statistically significant difference at 0.05 level & & & &
\end{tabular}

The fact that amotivation decreased in pre-service biology teachers at URCE after all interventions and increased in UTAB after intervention by the traditional method, animation-based instruction, and small group laboratory activities may result from the difference in the research designs applied during interventions. At URCE, a quasiexperimental of nonequivalent group control group design was used. This permitted them to be assigned to different groups where each group received treatment by only one instructional method. This helped them to focus on the usefulness of a single instructional method than in Pre-service biology teachers at UTAB, where they received series of interventions one after another by different instructional methods. Series of interventions at UTAB might create a boring and challenging learning environment as they repeated the same microbiology content by changing instructional methods. The same reason was also reported by students in a study by Planchard et al. (2015) found that boring or redundancy is one of the demotivating factors toward learning. 
On the side of students, the cause of a decrease in amotivation at URCE and an increase in UTAB may be attributed to their perceptions and appreciation that may be different on the used instructional methods. The findings do not tell that animation-based instruction and small group lab activities demotivate private university students toward learning biology as they are active instructional methods, but instructions should be carefully applied by avoiding research designs that involve assessment repetitions and learning content repetitions.

Though extrinsic motivation-career was high in pre-service biology teachers at URCE than in those at UTAB, instructional methods improved extrinsic motivationcareer in pre-service biology teachers after interventions at UTAB than in pre-service biology teachers at URCE. This improving effect of instructional methods at UTAB may explain low extrinsic motivation-career in Pre-service biology teachers at UTAB before joining university. It may also explain the strong effect of resource-based instructions that stimulated students to learn biology education as their future career, generating income when becoming professional biology teachers. The presence of high extrinsic motivation-career in pre-service biology teachers at URCE tells that they joined university with a commitment to learning biology with a defined learning goal or purpose of their future life.

A no statistically significant effect of the traditional method on the overall motivation of pre-service biology teachers toward learning biology at URCE is explained by teacher-centered characteristics of this instructional method that do not promote student's self-learning, self-determination, or stimulate them extrinsically to learn with goal orientation. This tells that by the traditional method, pre-serve biology teachers' motivation to learn biology may not continuously improve; instead may remain constant or tend to decrease. Contrary, the statistically significant effect of animation-based instructions and small group laboratory activities on motivation toward learning biology may result from the fact that those instructional methods are active, engaging, and attractive, thus may improve all aspects of motivation toward learning. The findings line with Bye et al. (2007), who also noticed an improvement in students' motivation to learn biology when active instructional methods are applied in the teaching and learning process. The implication is that resource-based instructions may improve students' motivation toward learning.

The fact that pre-service biology teachers at URCE were statistically significantly different based on their intrinsic motivation, amotivation, extrinsic motivation career, and social may results from their orientations to Universities after their 
secondary schools. Those pre-service biology teachers are oriented following different factors but mainly based on their performance in national exams. One may be oriented to a teacher training university, which is not their first choice or oriented in biology education which may not also be their subject of choice. This may create variability in their motivation toward learning biology, where some may be intrinsically motivated to learn biology while others are not. Some students may be extrinsically motivated with career goals, others may be extrinsically motivated with social values, and others may be demotivated to learn biology. This might be why the same difference was not statistically observed in pre-service service biology teachers at UTAB, where they join university and biology education subjects based on their real choice. The implication is the production of secondary school biology teachers with different motivations that may lead to the remarkable difference in competency among pre-service biology teachers who graduated from URCE.

\section{Conclusion and Recommendations}

The present study tested the effect of animation based-instruction and laboratory methods through small activities as resource-based instructions on pre-service biology teachers' motivation toward learning biology. The study was conducted at the University of Technology and Arts of Byumba (UTAB), a private university with Biology education programs, and at the University of Rwanda College of Education (URCE), a public teacher-training university. A survey design was used to collect the data during interventions by resource-based instructions. The findings revealed no statistically significant difference in motivation toward learning biology between preservice biology teachers at private university (UTAB) and public university (URCE). However, a statistically significant difference in motivation factors between universities was revealed. There was no significant difference in motivation toward learning biology in pre-service biology teachers taught by traditional methods at URCE. However, statistically, animation-based instruction and small group laboratory activities improved the overall motivation of pre-service biology teachers toward learning biology; therefore, they are recommended for teaching pre-service biology teachers motivation toward learning biology. At UTAB, no statistically significant difference $(\mathrm{df}=18, p=.660)$ between pre-assessment and traditional instruction, between traditional and animation-based instruction $(\mathrm{df}=18, p=.750)$, and between animation and lab instruction $(\mathrm{df}=18, p=.832)$. The similarity may result from the repetition of learned content that characterized interventions and may create 
a boring learning environment that did not increase pre-service biology teachers' motivation after each intervention series. The study is biased against participants at the public university. It might have been better to have used three universities and grouped each university to each of the interventions or stick to the public university alone because of the population reported. Therefore, we recommend using other research designs rather than repeated measures that involve multiple tests and interventions on a single group of participants. Instructional methods improved motivation factors in pre-service biology teachers, statistically traditional methods improved intrinsic motivation and reduced amotivation in pre-service biology teachers at URCE. At the same time, animation-based instructions increased both intrinsic and extrinsic motivation career but did not reduce amotivation toward learning biology.

\section{Acknowledgments}

We sincerely thank the African Center of Excellence for Innovative Teaching and Learning Mathematics and Science (ACEITLMS), which financially supported this study to be successfully conducted. We also thank the Universities that voluntarily participated in the study.

\section{References}

Adejimi, S., Nzabalirwa, W., \& Shivoga, W. (2021). Innovative collaborative instructional strategies: It's effect on secondary school students' achievement in biology as moderated by verbal ability. Lumat, 9(1), 495-517. https://doi.org/10.31129/LUMAT.9.1.1397

Aydin, S., Yerdelen, S., Yalmanci, S. G., \& Göksu, V. (2014). Academic motivation scale for learning biology: A scale development study. Egitim ve Bilim, 39(176), 425-435.

https://doi.org/10.15390/EB.2014.3678

Ayub, N. (2010). Effect of intrinsic and extrinsic motivation on academic performance. Pakistan Business Review, 8(July 2010), 363-372.

Bulic, M., \& Blazevic, I. (2020). The impact of online learning on student motivation in science and biology classes. Journal of Elementary Education, 13(1), 73-87. https://doi.org/10.18690/rei.13.1.73-87.2020

Bye, D., Pushkar, D., \& Conway, M. (2007). Motivation, interest, and positive affect in traditional and nontraditional undergraduate students. Adult Education Quarterly, 57(2), 141-158. https://doi.org/10.1177/0741713606294235

Chua, K. H., \& Karpudewan, M. (2017). The role of motivation and perceptions about science laboratory environment on lower secondary students' attitude towards science. Asia-Pacific Forum on Science Learning and Teaching, 18(2), 1-18.

Çimer, A. (2012). What makes biology learning difficult and effective: Students' views. Educational Research and Reviews, 7(3), 1-11. https://doi.org/10.5897/ERR11.205 
Cook, D. A., \& Artino, A. R. (2016). Motivation to learn: an overview of contemporary theories. Medical Education, 5O(10), 997-1014. https://doi.org/10.1111/medu.13074

Corkin, D. M., Horn, C., \& Pattison, D. (2017). The effects of an active learning intervention in biology on college students' classroom motivational climate perceptions, motivation, and achievement. Educational Psychology, 37(9), 1106-1124.

https://doi.org/10.1080/01443410.2017.1324128

Covington, M. V., \& Müeller, K. J. (2001). Intrinsic Versus Extrinsic Motivation: An Approach/Avoidance Reformulation. Educational Psychology Review, 13(2), 157-176. https://doi.org/10.1023/A:1009009219144

Creswell, J. W. (2012). Educational Research: Planning, Conducting, and Evaluating Quantitative and Qualitative Research (4th ed.). PEARSON.

Creswell, J. W. (2014). Research Design: Qualitative, Quantitative, and Mixed Methods Approaches (4th ed.). SAGE Publications Ltd. https://doi.org/ISBN: 978-1-4522-2609-5

Creswell, J. W. (2015). Educational research: Planning, Conducting, and Evaluating Quantitative and Qualitative Research (5th ed.). Pearson.

Cuthbert, P. F. (2005). The student learning process: Learning Styles or Learning Approaches? Teaching in Higher Education, 10(2), 235-249.

https://doi.org/10.1080/1356251042000337972

Deci, E. L., \& Ryan, R. M. (1985). Intrinsic motivation and self-determination in human behavior. Springer Science, Business media. https://doi.org/10.1007/978-1-4899-2271-7

Dohn, N. B., Fago, A., Overgaard, J., Madsen, P. T., \& Malte, H. (2016). Students' motivation toward laboratory work in physiology teaching. Advances in Physiology Education, 4O(3), 313-318. https://doi.org/10.1152/advan.00029.2016

Dyrberg, N. R., Treusch, A. H., \& Wiegand, C. (2017). Virtual laboratories in science education: students' motivation and experiences in two tertiary biology courses. Journal of Biological Education, 51(4), 358-374. https://doi.org/10.1080/00219266.2016.1257498

Ekici, G. (2010). Factors affecting biology lesseon motivation of high school students. Procedia Social and Behavioral Sciences, 2(2), 2137-2142.

https://doi.org/10.1016/j.sbspro.2010.03.295

Gilakjani, A. P., Leong, L.-M., \& Sabouri, N. B. (2012). A Study on the Role of Motivation in Foreign Language Learning and Teaching. International Journal of Modern Education and Computer Science, 4(7), 9-16. https://doi.org/10.5815/ijmecs.2012.07.02

Hewitt, K. M., Bouwma-Gearhart, J., Kitada, H., Mason, R., \& Kayes, L. J. (2019). Introductory biology in social context: The effects of an issues-based laboratory course on biology student motivation. CBE Life Sciences Education, 18(3), ar30. https://doi.org/10.1187/cbe.18-070110

Jurisevic, M., Glazar, S., Pucko, C. R., \& Devetak, I. (2008). Intrinsic motivation of pre-service primary school teachers for learning chemistry in relation to their academic achievement. International Journal of Science Education, 30(1), 87-107.

https://doi.org/10.1080/09500690601148517

Keraro, F. N., Wachanga, S. W., \& Orora, W. (2007). Effects of cooperative concept mapping teaching approach on secondary school students' motivation in biology in Gucha District, Kenya. International Journal of Science and Mathematics Education, 5(1), 111-124. https://doi.org/10.1007/s10763-005-9026-3

Kibga, E. S., Gakuba, E., \& Sentongo, J. (2021). Developing Students' Curiosity Through Chemistry Hands-on Activities: A Case of Selected Community Secondary Schools in Dar es Salaam, Tanzania. Eurasia Journal of Mathematics, Science and Technology Education, 17(5), 1-17. https://doi.org/10.29333/ejmste/10856 
Kişoğlu, M. (2018). An Examination of Science High School Students' Motivation towards Learning Biology and Their Attitude Towards Biology Lesson. International Journal of Higher Education, 7(1), 151-164. https://doi.org/10.5430/ijhe.v7n1p151

Koul, R., Lerdpornkulrat, T., \& Chantara, S. (2011). Relationship Between Career Aspirations and Measures of Motivation Toward Biology and Physics, and the Influence of Gender. Journal of Science Education and Technology, 20(6), 761-770. https://doi.org/10.1007/s10956-0109269-9

Mnguni, L., \& Moyo, D. (2018). The motivation level of Soweto students towards learning biology. XII Conference of the European Researchers in Didactics of Biology, July, v. 2 p. 6.

Mukagihana, J., Aurah, C. M., \& Nsanganwimana, F. (2021). The Effect of Resource-Based Instructions on Pre-service Biology Teachers' Attitudes towards Learning Biology. International Journal of Learning, Teaching and Educational Research, 20(8), 262-277. https://doi.org/https://doi.org/10.26803/ijlter.20.8.16

Mukagihana, J., Nsanganwimana, F., \& Aurah, C. (2020). Biology Instructional Resources Availability and Extent of their Utilization in Teaching Pre-Service Biology Teachers. African Journal of Educational Studies in Mathematics and Sciences, 16(2), 33-50. https://doi.org/10.4314/ajesms.v16i2.3

Mukagihana, J., Nsanganwimana, F., \& Aurah, C. M. (2021). How Pre-service Teachers Learn Microbiology using Lecture, Animations, and Laboratory Activities at one Private University in Rwanda. International Journal of Learning, Teaching and Educational Research, 2O(7), 328-345. https://doi.org/https://doi.org/10.26803/ijlter.20.7.18

Ndihokubwayo, K., Nyirahabimana, P., \& Musengimana, T. (2021). Teaching and Learning Bucket Model: Experimented with Mechanics Baseline Test. European Journal of Educational Research, 10(2), 525-536. https://doi.org/10.12973/eu-jer.10.2.525

Ndihokubwayo, K., Shimizu, K., Ikeda, H., \& Baba, T. (2019). An Evaluation of the Effect of the Improvised Experiments on Student-teachers' Conception of Static Electricity. LWATI: A Journal of Contemporary Research, 16(1), 55-73. https://www.ajol.info/index.php/lwati/article/view/185967

Özarslan, M., \& Çetin, G. (2018). Effects of biology project studies on gifted and talented students' motivation toward learning biology. Gifted Education International, 34(3), 205-221. https://doi.org/10.1177/0261429417754203

Özbaş, S. (2019). High school students' motivation towards biology learning. Çukurova Üniversitesi Eğitim Fakültesi Dergisi Vol:, 48(1), 945-959. https://doi.org/10.14812/cufej.293029

Planchard, M., Daniel, K. L., Maroo, J., Mishra, C., \& McLean, T. (2015). Homework, motivation, and academic achievement in a college genetics course. Bioscene, 41(2), 11-18.

Prokop, P., Prokop, M., \& Tunnicliffe, S. D. (2007). Is biology boring? Student attitudes toward biology. Journal of Biological Education, 42(1), 36-39. https://doi.org/10.1080/00219266.2007.9656105

Reiss, S. (2012). Intrinsic and Extrinsic Motivation. In Teaching of Psychology (Vol. 39, Issue 2, pp. 152-156). https://doi.org/10.1177/0098628312437704

Ryan, R. M., \& Deci, E. L. (2000). Intrinsic and Extrinsic Motivations: Classic Definitions and New Directions. Contemporary Educational Psychology, 25(1), 54-67. https://doi.org/10.1006/ceps.1999.1020

Şen, Ş., Yilmaz, A., \& Yurdugül, H. (2014). An Evaluation of the Pattern between Students' Motivation, Learning Strategies and Their Epistemological Beliefs: The Mediator Role of Motivation. International Association on Science Education International, 24(3), 312-331. 
Shin, S., Lee, J. K., \& Ha, M. (2017). Influence of career motivation on science learning in Korean high-school students. Eurasia Journal of Mathematics, Science and Technology Education, 13(5), 1517-1538. https://doi.org/10.12973/eurasia.2017.00683a

\section{Appendix A. Adapted Academic Motivation Scale for Learning Biology (AMSLB)}

\begin{tabular}{|c|c|c|c|c|c|}
\hline \multirow[b]{2}{*}{ Items } & \multicolumn{5}{|c|}{ Level of agreement } \\
\hline & SD & $\mathrm{D}$ & NO & A & SA \\
\hline \multicolumn{6}{|l|}{ Intrinsic Motivation } \\
\hline \multicolumn{6}{|c|}{ 1. I enjoy making discussions on biology subjects } \\
\hline \multicolumn{6}{|c|}{ 2. Learning new things in the biology subjects that I am interested in is enjoyable. } \\
\hline \multicolumn{6}{|c|}{ 3. I enjoy sharing the new things that I learn in biology. } \\
\hline \multicolumn{6}{|l|}{ 4. Biology subjects interest me. } \\
\hline \multicolumn{6}{|l|}{ 5. I enjoy learning biology subjects. } \\
\hline 6. I enjoy reading magazines and texts related to biology & & & & & \\
\hline
\end{tabular}
Amotivation

7. To be honest, I don't see any reason for learning biology.

8. Actually, I don't think the subjects that I learn will be useful for me in the future

9. Honestly, I don't know why I should learn biology.

10. I have no idea. I don't understand how useful the things I learn will be.

11. In fact, I don't like participating the activities in biology.

\section{Extrinsic Motivation - Career}

12. I learn biology because it is related to the profession that I chose for my future.

13. I learn biology because it is important in my choice of profession.

14. I learn biology to get a good job in the field of biology.

15. I learn biology to be able to make better choices for my further studies

\section{Extrinsic Motivation - Social}

16. I learn biology to show my family that I'm successful in biology.

17. I learn biology to prove myself that I can be successful in biology

18. I learn biology to show that I'm better than the other students.

19. I want to be praised by the people around me. 